Review

\title{
High doses of melatonin as a potential therapeutic tool for the neurologic sequels of covid-19 infection
}

\section{Daniel P. Cardinali}

Faculty of Medical Sciences, Pontificia Universidad Católica Argentina, Buenos Aires, Argentina

Correspondence: daniel_cardinali@uca.edu.ar; danielcardinali@fibertel.com.ar, Tel: +54 911 44743547

Running title: Melatonin and the neurologic sequels of covid-19 infection

Received: April 21, 2020; Accepted: June 4, 2020

\begin{abstract}
The therapeutic potential of melatonin as an agent to counteract the consequences of COVID-19 infections is due to its wide-ranging effects as a powerful antioxidant, antiinflammatory, and immunostimulant, as well as to a possible antiviral action. In view of the recently reported evidence on the occurrence of neurological sequels in COVID-19-infected patients, another putative application of melatonin emerges based on its neuroprotective properties. In this manuscript a brief discussion of melatonin activity in animal models of ischemic and hemorrhagic stroke and the allometric calculations of the possible human equivalent doses are made. Based on the safety of melatonin, and in order to maximize its therapeutic opportunity, doses of $100-300 \mathrm{mg}$ p.o. or i.v. are proposed.
\end{abstract}

Key words: allometry, COVID-19, cytoprotection, inflammation, melatonin, stroke

\section{INTRODUCTION}

In light of the public health problem triggered by the spread of COVID-19 and in the face of essentially null options for prevention or treatment presently available, the use of melatonin has been proposed to possibly control the consequences of the disease (1). In severely infected patients with COVID-19, clinical findings indicate that excessive inflammation, a depressed immune system, and activated cytokine storm contribute substantially to pulmonary pathogenesis (2). In addition, in a recently published retrospective consecutive case series of 214 patients from Wuhan, China, with either moderate or severe COVID-19, 36.4\% exhibited some nervous system-related clinical finding (3). A report of viral infiltration of the brainstem in pathologic specimens (4) also raises the possibility that some of the crucial pathophysiology behind respiratory failure in COVID-19 may be owing to central nervous system pathology, further expanding the view of which clinical manifestations of the current pandemic are truly neurologic in nature. Moreover, at this time of compulsory and massive isolations or quarantine, patients with symptoms of stroke have higher chances of death or disability. 


\section{EVIDENCE FOR THE THERAPEUTIC VALUE OF MELATONIN IN STROKE}

Stroke is the second leading cause of death and a major cause of disability worldwide and its incidence is increasing because the population ages (5). In addition, more young people are affected by stroke in low- and middle-income countries. Ischemic stroke is more frequent but hemorrhagic stroke is responsible for more deaths and disability-adjusted life-years lost (5).

Melatonin, a methoxyindole present in all forms of life with aerobic respiration and, whose primary function seems to be cytoprotection, has indirect antiviral actions $(1,6)$ as an antiinflammatory, antioxidant and immunostimulant effects $(7,8)$ and a very effective neuroprotective activity (9). In mice with viral encephalitis, the administration of melatonin reduced viremia and viral load, improving the neurological sequelae and death of infected animals (10).

Melatonin exerts anti-inflammatory effects through various pathways. One of them is sirtuin-1, which inhibits the polarization of macrophages towards the proinflammatory type $(11,12)$. The anti-inflammatory effect of melatonin also includes the suppression of NF- $\kappa \mathrm{B}$ activation (13-15). Likewise, the production of $\mathrm{Nrf} 2$ is stimulated by melatonin in hepatoprotection and cardioprotection studies (16). Inflammation is commonly associated with elevated production of cytokines and chemokines. Melatonin causes a reduction of proinflammatory cytokines (TNF- $\alpha$, IL-1 $\beta$, IL-6, L-8, IL-17) and an elevation in the level of anti-inflammatory cytokines such as IL-10 $(11,17)$.

In both the cytoplasm and the cell nucleus, melatonin has important antioxidant and scavenging effects on free radicals, which are largely independent of receptors (18). These effects are exerted in three ways: (a) melatonin is a free radical scavenger; (b) melatonin is metabolized to compounds with high antioxidant activity; (c) melatonin is an indirect antioxidant, which stimulates the synthesis of antioxidant enzymes and inhibits that of prooxidant enzymes. Melatonin has a proven superiority to vitamin $\mathrm{C}$ and $\mathrm{E}$ in protection against oxidative damage and in the elimination of free radicals (19). In addition, melatonin potentiates the effects of other antioxidants, such as vitamin $\mathrm{C}$ and Trolox. Several antiapoptotic and cytoprotective effects of melatonin are exerted under conditions of ischemia (unrelated to free radicals) and can be attributed to the stabilizing activity of the mitochondrial membrane (20).

Tables 1 and 2 summarize the effect of melatonin in animal models of hemorrhagic and ischemic stroke. From the doses of melatonin used in the experiment listed in Tables 1 and 2, the human equivalent dose (HED) of melatonin for a $75 \mathrm{~kg}$ adult was calculated by allometry. Allometry is an engineering term derived from the Greek alloios (meaning different) that defines the study of size and its consequences (21). Allometry applies to properties whose proportions change as a function of size, as opposed to isometry whose relationship to size remains constant. Body surface area, rather than body weight, correlates well across several mammalian species with several parameters of biology, including oxygen utilization, caloric expenditure, basal metabolism, blood volume, circulating plasma proteins, and renal function, and has been advocated as a factor to be used when converting a dose for translation from animals to humans (22). Allometry is commonly used for determining doses for Phase I human clinical drug trials. In clinical medicine, it is feasible to use adult data to predict drug pharmacokinetic parameters in children, which can significantly decrease the occurrences of toxicity and mortality for new drugs used early in children. Noteworthy, theoretical human equivalent doses calculated from Table 1 and 2's results ranged from 2- to 3-orders of magnitude greater than those usually employed in humans. 
Table 1. Effect of melatonin on animal models of hemorrhagic stroke. The human equivalent dose (HED) of melatonin for a $75 \mathrm{~kg}$ adult is calculated allometrically (22).

\begin{tabular}{|c|c|c|c|c|}
\hline Model & $\begin{array}{l}\text { Melatonin } \\
\text { doses }\end{array}$ & $\begin{array}{l}\text { HED for a } \\
75 \mathrm{~kg} \text { adult }\end{array}$ & Melatonin's effects & Ref. \\
\hline $\begin{array}{l}\text { Rat / Model of subarachnoid } \\
\text { hemorrhage from cisterna } \\
\text { magna. }\end{array}$ & $\begin{array}{l}10 \mathrm{mg} / \mathrm{kg}, \text { i.p., } \\
\text { repeated daily } \\
\text { for } 2 \text { days. }\end{array}$ & $121 \mathrm{mg}$ & $\begin{array}{l}\text { Inhibits lipid peroxidation, restores } \\
\text { glutathione levels }\end{array}$ & (23) \\
\hline $\begin{array}{l}\text { Rat / Model of subarachnoid } \\
\text { hemorrhage from } \\
\text { Prechiasmatic Cistern. }\end{array}$ & $\begin{array}{l}150 \mathrm{mg} \mathrm{/} \mathrm{kg}, \\
\text { i.p., } 2 \text { and } 24 \mathrm{~h} \\
\text { later. }\end{array}$ & $1824 \mathrm{mg}$ & $\begin{array}{l}\text { Activates the Nrf2-ARE pathway } \\
\text { and increases the expression of } \\
\text { detoxifying enzymes and } \\
\text { antioxidants }\end{array}$ & (24) \\
\hline $\begin{array}{l}\text { Rat / Model of subarachnoid } \\
\text { hemorrhage by endovascular } \\
\text { filament. }\end{array}$ & $\begin{array}{l}150 \mathrm{mg} \mathrm{/} \mathrm{kg}, \\
\text { i.p., } 2 \text { and } 24 \mathrm{~h} \\
\text { later. }\end{array}$ & $1824 \mathrm{mg}$ & $\begin{array}{l}\text { Reduces the water content in the } \\
\text { brain, reduces mortality }\end{array}$ & $(25)$ \\
\hline $\begin{array}{l}\text { Rat / Model of subarachnoid } \\
\text { hemorrhage by endovascular } \\
\text { filament. }\end{array}$ & $\begin{array}{l}150 \mathrm{mg} \mathrm{/} \mathrm{kg}, \\
\text { i.p., } 2 \text { h later. }\end{array}$ & $1824 \mathrm{mg}$ & $\begin{array}{l}\text { Improves autophagy, inhibits } \\
\text { mitochondria-dependent apoptosis }\end{array}$ & (26) \\
\hline $\begin{array}{l}\text { Rat / Model of subarachnoid } \\
\text { hemorrhage by endovascular } \\
\text { filament. }\end{array}$ & $\begin{array}{l}150 \mathrm{mg} \mathrm{/} \mathrm{kg} \text {, } \\
\text { i.p., } 2 \mathrm{~h} \text { later. }\end{array}$ & $1824 \mathrm{mg}$ & $\begin{array}{l}\text { Inhibits proinflammatory } \\
\text { cytokines, maintains close binding } \\
\text { proteins and BBB integrity }\end{array}$ & (27) \\
\hline $\begin{array}{l}\text { Rat / Model of subarachnoid } \\
\text { hemorrhage by endovascular } \\
\text { filament. }\end{array}$ & $\begin{array}{l}150 \mathrm{mg} \mathrm{/} \mathrm{kg}, \\
\text { i.p., } 2 \text { and } 24 \mathrm{~h} \\
\text { later. }\end{array}$ & $1824 \mathrm{mg}$ & $\begin{array}{l}\text { Decreases the expression of } \\
\text { mediators related to the TLR4 } \\
\text { pathway }\end{array}$ & $(28)$ \\
\hline $\begin{array}{l}\text { Rabbit I Model of } \\
\text { subarachnoid } \\
\text { from cisterna magna. }\end{array}$ & $\begin{array}{l}5 \mathrm{mg} / \mathrm{kg} \text {, i.p., } \\
\text { every } 12 \mathrm{~h} \text { for } 5 \\
\text { days. }\end{array}$ & $243 \mathrm{mg}$ & $\begin{array}{l}\text { Reduces the activity of arterial NF- } \\
\mathrm{kB}, \text { decreases the vascular levels of } \\
\mathrm{IL}-1 \beta \text {, IL- } 6 \text { and TNF- } \alpha \text {, improves } \\
\text { the antioxidant defense system, and } \\
\text { reduces lipid peroxidation }\end{array}$ & (29) \\
\hline $\begin{array}{l}\text { Rat } / \text { collagenase-induced } \\
\text { intracerebral hemorrhage } \\
\text { model. }\end{array}$ & $\begin{array}{l}15 \mathrm{mg} / \mathrm{kg} \text {, oral, } \\
\text { and every } 24 \\
\text { hours thereafter } \\
\text { for } 7 \text { days. }\end{array}$ & $182 \mathrm{mg}$ & 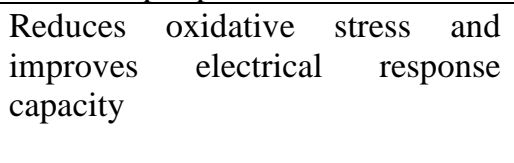 & $(30)$ \\
\hline $\begin{array}{l}\text { Rat / collagenase-induced } \\
\text { intracerebral hemorrhage } \\
\text { model. }\end{array}$ & $\begin{array}{l}15 \text { or } 150 \mathrm{mg} / \\
\text { kg, i.p., } 15 \mathrm{~min} \\
\text { and } 3 \mathrm{~h} \text { after. }\end{array}$ & $\begin{array}{l}365 \text { or } 3650 \\
\mathrm{mg}\end{array}$ & Decreases lipid peroxidation & (31) \\
\hline $\begin{array}{l}\text { Rat I collagenase-induced } \\
\text { intracerebral hemorrhage } \\
\text { model. }\end{array}$ & $\begin{array}{l}15 \mathrm{mg} / \mathrm{kg}, \text { i.p., } \\
1,24,48 \text { and } 72 \\
\text { h later. }\end{array}$ & $182 \mathrm{mg}$ & $\begin{array}{l}\text { Relieves long-term brain atrophy } \\
\text { and reverses striatal and cognitive } \\
\text { functional deficiency }\end{array}$ & $(32)$ \\
\hline
\end{tabular}

Table 2. Effect of melatonin on animal models of ischemic stroke. The human equivalent dose (HED) of melatonin for a $75 \mathrm{~kg}$ adult is calculated allometrically (22).

\begin{tabular}{|c|c|c|c|c|}
\hline Model & Melatonin doses & $\begin{array}{l}\text { HED for a } \\
75 \mathrm{~kg} \text { adult }\end{array}$ & Melatonin's effect & Ref. \\
\hline $\begin{array}{l}\text { Rat / middle cerebral artery } \\
\text { occlusion. }\end{array}$ & $\begin{array}{l}20 \mathrm{mg} / \mathrm{kg} \text { p.o. } \\
\text { before occlusion } \\
\text { and once a day for } \\
11 \text { or } 19 \text { days. }\end{array}$ & $243 \mathrm{mg}$ & Improves glial cell survival. & (33) \\
\hline $\begin{array}{l}\text { Rat / middle cerebral artery } \\
\text { occlusion. }\end{array}$ & $\begin{array}{l}6.0 \mathrm{mg} / \mathrm{kg} \text {, p.o.) } \\
\text { before occlusion } \\
\text { and } 1 \text { day after } \\
\text { surgery. }\end{array}$ & $73 \mathrm{mg}$ & $\begin{array}{l}\text { Reduces ischemia-induced } \\
\text { edema. }\end{array}$ & (34) \\
\hline $\begin{array}{l}\text { Rat / middle cerebral artery } \\
\text { occlusion. }\end{array}$ & $\begin{array}{l}5 \mathrm{mg} / \mathrm{kg} \text { i.v. at the } \\
\text { start of reperfusion. }\end{array}$ & $60 \mathrm{mg}$ & $\begin{array}{l}\text { Attenuates the stress of the } \\
\text { endoplasmic reticulum. }\end{array}$ & $(35)$ \\
\hline
\end{tabular}




\begin{tabular}{|c|c|c|c|c|}
\hline $\begin{array}{l}\text { Rat / transient focal } \\
\text { cerebral ischemia. }\end{array}$ & $\begin{array}{l}5 \mathrm{mg} / \mathrm{kg} \text { i.v. at the } \\
\text { start of reperfusion. }\end{array}$ & $60 \mathrm{mg}$ & $\begin{array}{l}\text { Ensures the preservation of the } \\
\text { blood-brain barrier and the } \\
\text { neurovascular unit. }\end{array}$ & (36) \\
\hline $\begin{array}{l}\text { Rat / transient focal } \\
\text { cerebral ischemia. }\end{array}$ & $\begin{array}{l}5 \mathrm{mg} / \mathrm{kg} \text { i.v. at the } \\
\text { start of reperfusion. }\end{array}$ & $60 \mathrm{mg}$ & $\begin{array}{l}\text { Inhibits the cellular } \\
\text { inflammatory response. }\end{array}$ & (37) \\
\hline Rat / brain ischemia injury. & $\begin{array}{l}15 \mathrm{mg} / \mathrm{kg} \text { after the } \\
\text { hypoxic-ischemic } \\
\text { event and for } 2 \\
\text { days. }\end{array}$ & $180 \mathrm{mg}$ & $\begin{array}{l}\text { Neuroprotection (reduction of } \\
\text { cell death, reactive astrogliosis, } \\
\text { and white matter } \\
\text { demyelination). }\end{array}$ & $(38)$ \\
\hline $\begin{array}{l}\text { Rat / transient global } \\
\text { cerebral ischemia. }\end{array}$ & $\begin{array}{l}\text { continuous infusion } \\
\text { i.v. }(10 \mathrm{mg} / \mathrm{kg} / \mathrm{h} \\
\text { for } 6 \mathrm{~h}) .\end{array}$ & $720 \mathrm{mg}$ & $\begin{array}{l}\text { Preserves the neural substrate, } \\
\text { spatial learning and memory. }\end{array}$ & (39) \\
\hline $\begin{array}{l}\text { Gerbil / middle cerebral } \\
\text { artery occlusion. }\end{array}$ & $\begin{array}{l}10 \mathrm{mg} / \mathrm{kg} \text { i.p. } 30 \\
\text { min before } \\
\text { reperfusion and } 1,2 \\
\text { and } 6 \text { hours later. }\end{array}$ & $324 \mathrm{mg}$ & 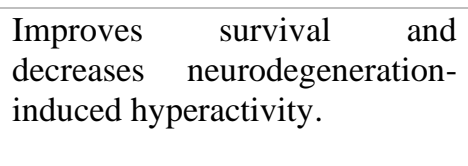 & $(40)$ \\
\hline $\begin{array}{l}\text { Rat / middle cerebral artery } \\
\text { occlusion. }\end{array}$ & $\begin{array}{l}10 \mathrm{mg} / \mathrm{kg} \text { i.p } 15 \\
\text { min before focal } \\
\text { ischemia and } 6 \mathrm{~h} \\
\text { and } 12 \mathrm{~h} \text { later. }\end{array}$ & $364 \mathrm{mg}$ & $\begin{array}{l}\text { Reduces infarct size and DNA } \\
\text { damage. }\end{array}$ & $(41)$ \\
\hline $\begin{array}{l}\text { Rat / middle cerebral artery } \\
\text { occlusion. }\end{array}$ & $\begin{array}{l}5 \mathrm{mg} / \mathrm{kg} \text { i.p. at } 0,1 \\
\text { or } 3 \text { hours after } \\
\text { ischemia. }\end{array}$ & $182 \mathrm{mg}$ & $\begin{array}{l}\text { Reduces infarct size and } \\
\text { improves the antioxidant state in } \\
\text { a time-dependent manner. }\end{array}$ & $(42)$ \\
\hline $\begin{array}{l}\text { Mouse / middle cerebral } \\
\text { artery occlusion. }\end{array}$ & $\begin{array}{l}10 \mathrm{mg} / \mathrm{kg} \text { i.p given } \\
\text { twice. }\end{array}$ & $60 \mathrm{mg}$ & $\begin{array}{l}\text { Up-regulates SIRT 1, increases } \\
\text { antiapoptotic factor, and } \\
\text { decreases proapoptotic factor } \\
\text { activity. }\end{array}$ & $(43)$ \\
\hline $\begin{array}{l}\text { Mouse / middle cerebral } \\
\text { artery occlusion and oxygen } \\
\text { and glucose deprivation. }\end{array}$ & $\begin{array}{l}10 \mathrm{mg} / \mathrm{kg} \text { i.p } 15 \\
\text { min before focal } \\
\text { ischemia and } 6 \mathrm{~h} \\
\text { and } 12 \mathrm{~h} \text { later. }\end{array}$ & $180 \mathrm{mg}$ & $\begin{array}{l}\text { Decreases oxidative stress and } \\
\text { inhibits the release of } \\
\text { mitochondrial cytochrome C. }\end{array}$ & (44) \\
\hline $\begin{array}{l}\text { Mouse / middle cerebral } \\
\text { artery occlusion. }\end{array}$ & $\begin{array}{l}5 \mathrm{mg} / \mathrm{kg} \text {, i.p., } 60 \\
\text { min after the onset } \\
\text { of ischemia. }\end{array}$ & $30 \mathrm{mg}$ & $\begin{array}{l}\text { Attenuates postischemic } \\
\text { increase in blood-brain barrier } \\
\text { permeability and improves t-PA } \\
\text { therapy. }\end{array}$ & $(45)$ \\
\hline $\begin{array}{l}\text { Mouse / middle cerebral } \\
\text { artery occlusion. }\end{array}$ & $\begin{array}{l}5 \mathrm{mg} / \mathrm{kg} \text {, i.p., } 90 \\
\text { min after the onset } \\
\text { of ischemia. }\end{array}$ & $30 \mathrm{mg}$ & $\begin{array}{llr}\text { Negatively } & \text { regulates } & \text { post } \\
\text { ischemic activation } & \text { and } \\
\text { expression of MMP-9 } & \text { and } \\
\text { improves t-PA therapy. } & \end{array}$ & $(46)$ \\
\hline
\end{tabular}

\section{SAFETY FOR THE CLINICAL USE OF MELATONIN}

Melatonin is remarkably non-toxic, and its safety is very high. The lethal dose 50 for intraperitoneal injection of melatonin was determined for rats $(1168 \mathrm{mg} / \mathrm{kg})$ and mice $(1131$ $\mathrm{mg} / \mathrm{kg}$ ), but could not be achieved after oral administration of melatonin (tested up to 3200 $\mathrm{mg} / \mathrm{kg}$ in rats or subcutaneous injection of melatonin (tested up to $1600 \mathrm{mg} / \mathrm{kg}$ in rats and mice) (47). There is evidence in dose escalation experiments of the remarkable lack of toxicity of melatonin in humans up to $100 \mathrm{mg}(48,49)$. As discussed elsewhere (50), high doses of melatonin have been used in various pathologies without undesirable sequelae, that is, in humans, melatonin has a high safety profile and, in general, is very well tolerated. 


\section{CONCLUSIONS}

Allometric calculations of the HED of Tables 1 and 2 strongly indicate that effective melatonin doses in COVID-19 patients must be in the 100-300 mg / day range. Although there is no report related to the use of melatonin in patients with COVID-19, in subjects with other diseases and a higher level of inflammation, the application of melatonin may show promising results with strong attenuation of circulating cytokine levels. This was documented in patients with diabetes mellitus and periodontitis (51) and severe multiple sclerosis (52). In the acute phase of inflammation, during surgical stress (53), cerebral reperfusion (54) or reperfusion of the coronary artery (55), treatment with melatonin reduced the level of proinflammatory cytokines.

According to the COVID-19 clinical reports, patients with severe infection have an increased risk of sepsis and cardiac arrest $(56,57)$. The available information indicates that the application of melatonin can improve septic shock through inhibition of the NLRP3 pathway (58). Specifically, melatonin has a preventive effect against sepsis-induced kidney damage, septic cardiomyopathy, and liver damage (59-61). Melatonin has also been reported as beneficial in patients with myocardial infarction, cardiomyopathy, hypertensive heart disease, and pulmonary hypertension, and that it exerts neurological protection by reducing the inflammatory response in the brain, cerebral edema, and hyperpermeability of the blood-brain barrier. In the ICU, deep sedation is associated with increased long-term mortality, and the application of melatonin reduces the use of sedation and the frequency of pain, agitation and anxiety $(62,63)$ and improves the quality of sleep. Therefore, the rationale for the use of high doses of melatonin in COVID-19 focuses not only on attenuation of infection-induced respiratory disorders, but also on general improvement and prevention of possible complications, like the neurologic ones.

\section{ACKNOWLEDGEMENTS}

DPC is an Emeritus Superior Investigator from the Argentine National Research Council (CONICET) and Emeritus Professor, University of Buenos Aires.

\section{CONFLICT OF INTEREST}

The author declares that there are no commercial or financial relationships that could be construed as a potential conflict of interest.

\section{REFERENCES}

1 Reiter RJ, Ma Q, Sharma S (2020) Treatment of Ebola and other infectious diseases: melatonin "goes viral". Melatonin Res. 3: 43-57. doi: 10.32794/mr11250047.

2 Tan DX, Hardeland R (2020) Potential utility of melatonin in deadly infectious diseases related to the overreaction of innate immune response and destructive inflammation: focus on COVID-19. Melatonin Res. 3: 120-143. doi: 10.32794/mr11250052.

3 Mao L, Jin H, Wang M, Hu Y, Chen S, He Q, et al. (2020) Neurologic manifestations of hospitalized patients with coronavirus disease 2019 in Wuhan, China. JAMA Neurol. doi: 10.1001/jamaneurol.2020.1127.

4 Li YC, Bai WZ, Hashikawa T (2020) The neuroinvasive potential of SARS-CoV2 may play a role in the respiratory failure of COVID-19 patients. J. Med. Virol. doi: 10.1002/jmv.25728 doi: 10.1002/jmv.25728. 
5 Kaji R (2019) Global burden of neurological diseases highlights stroke. Nat. Rev. Neurol. 15: 371-372. doi: 10.1038/s41582-019-0208-y.

6 Zhang R, Wang X, Ni L, Di X, Ma B, Niu S, et al. (2020) COVID-19: Melatonin as a potential adjuvant treatment. Life Sci. 250: 117583 . doi: 10.1016/j.lfs.2020.117583.

7 Maestroni GJ (1999) Therapeutic potential of melatonin in immunodeficiency states, viral diseases, and cancer. Adv. Exp. Med. Biol. 467: 217-226. DOI: 10.1007/978-1-4615-4709$9 \_28$.

8 Anderson G, Maes M, Markus RP, Rodriguez M (2015) Ebola virus: melatonin as a readily available treatment option. J. Med. Virol. 87: 537-543. doi: 10.1002/jmv. 24130.

9 Cardinali DP (2019) Melatonin: clinical perspectives in neurodegeneration. Front Endocrinol. (Lausanne) 10: 480. doi: 10.3389/fendo.2019.00480.

10 Ben-Nathan D, Maestroni GJ, Lustig S, Conti A (1995) Protective effects of melatonin in mice infected with encephalitis viruses. Arch. Virol. 140: 223-30. DOI: 10.1007/bf01309858.

11 Hardeland R (2018) Melatonin and inflammation-Story of a double-edged blade. J. Pineal Res. 65: e12525. doi: 10.1111/jpi.12525.

12 Xia Y, Chen S, Zeng S, Zhao Y, Zhu C, Deng B, et al. (2018) Melatonin in macrophage biology: current understanding and future perspectives. J. Pineal Res. 66 (2): e12547. doi: 10.1111/jpi.12547.

13 Pedrosa AM, Weinlich R, Mognol GP, Robbs BK, Viola JP, Campa A, et al. (2010) Melatonin protects CD4+ T cells from activation-induced cell death by blocking NFATmediated CD95 ligand upregulation. J. Immunol. 184: 3487-3494. doi: 10.4049/jimmunol.0902961.

14 Shang Y, Xu SP, Wu Y, Jiang YX, Wu ZY, Yuan SY, et al. (2009) Melatonin reduces acute lung injury in endotoxemic rats. Chin. Med. J. (Engl ) 122: 1388-1393.

15 Deng WG, Tang ST, Tseng HP, Wu KK (2006) Melatonin suppresses macrophage cyclooxygenase-2 and inducible nitric oxide synthase expression by inhibiting p52 acetylation and binding. Blood 108: 518-524. DOI: 10.1182/blood-2005-09-3691.

16 Ahmadi Z, Ashrafizadeh M (2020) Melatonin as a potential modulator of Nrf2. Fundam. Clin. Pharmacol. 34: 11-19. doi: 10.1111/fcp.12498.

17 Habtemariam S, Daglia M, Sureda A, Selamoglu Z, Gulhan MF, Nabavi SM (2017) Melatonin and respiratory diseases: a review. Curr. Top. Med. Chem. 17: 467-488. DOI: $10.2174 / 1568026616666160824120338$.

18 Manchester LC, Coto-Montes A, Boga JA, Andersen LP, Zhou Z, Galano A, et al. (2015) Melatonin: an ancient molecule that makes oxygen metabolically tolerable. J. Pineal Res. 59: 403-419. doi: 10.1111/jpi.12267.

19 Galano A, Tan DX, Reiter RJ (2011) Melatonin as a natural ally against oxidative stress: a physicochemical examination. J. Pineal Res. 51: 1-16. doi: 10.1111/j.1600079X.2011.00916.x.

20 Reiter RJ, Tan DX, Rosales-Corral S, Galano A, Jou MJ, Acuña-Castroviejo D (2018) Melatonin mitigates mitochondrial meltdown: interactions with SIRT3. Int. J. Mol. Sci. 19 (8): pii: E2439. doi: 10.3390/ijms19082439.

21 Huang Q, Riviere JE (2014) The application of allometric scaling principles to predict pharmacokinetic parameters across species. Expert. Opin. Drug Metab. Toxicol. 10: 12411253.

22 Reagan-Shaw S, Nihal M, Ahmad N (2008) Dose translation from animal to human studies revisited. FASEB J. 22: 659-661. DOI: 10.1096/fj.07-9574LSF.

23 Ersahin M, Toklu HZ, Cetinel S, Yuksel M, Yegen BC, Sener G (2009) Melatonin reduces experimental subarachnoid hemorrhage-induced oxidative brain damage and neurological symptoms. J. Pineal Res. 46: 324-332. doi: 10.1111/j.1600-079X.2009.00664.x. 
24 Wang Z, Ma C, Meng CJ, Zhu GQ, Sun XB, Huo L, et al. (2012) Melatonin activates the Nrf2-ARE pathway when it protects against early brain injury in a subarachnoid hemorrhage model. J. Pineal Res. 53: 129-137. doi: 10.1111/j.1600-079X.2012.00978.x.

25 Ayer RE, Sugawara T, Chen W, Tong W, Zhang JH (2008) Melatonin decreases mortality following severe subarachnoid hemorrhage. J. Pineal Res. 44: 197-204. doi: 10.1111/j.1600-079X.2007.00508.x.

26 Chen J, Wang L, Wu C, Hu Q, Gu C, Yan F, et al. (2014) Melatonin-enhanced autophagy protects against neural apoptosis via a mitochondrial pathway in early brain injury following a subarachnoid hemorrhage. J. Pineal Res. 56: 12-19. doi: 10.1111/jpi.12086.

27 Chen J, Chen G, Li J, Qian C, Mo H, Gu C, et al. (2014) Melatonin attenuates inflammatory response-induced brain edema in early brain injury following a subarachnoid hemorrhage: a possible role for the regulation of pro-inflammatory cytokines. J. Pineal Res. 57: 340-347. doi: 10.1111/jpi.12173.

28 Wang Z, Wu L, You W, Ji C, Chen G (2013) Melatonin alleviates secondary brain damage and neurobehavioral dysfunction after experimental subarachnoid hemorrhage: possible involvement of TLR4-mediated inflammatory pathway. J. Pineal Res. 55: 399-408. doi: 10.1111/jpi.12087.

29 Fang Q, Chen G, Zhu W, Dong W, Wang Z (2009) Influence of melatonin on cerebrovascular proinflammatory mediators expression and oxidative stress following subarachnoid hemorrhage in rabbits. Mediators Inflamm. 2009: 426346. doi: $10.1155 / 2009 / 426346$.

30 Ueda Y, Masuda T, Ishida A, Misumi S, Shimizu Y, Jung CG, et al. (2014) Enhanced electrical responsiveness in the cerebral cortex with oral melatonin administration after a small hemorrhage near the internal capsule in rats. J. Neurosci. Res. 92: 1499-1508. doi: 10.1002/jnr.23434.

31 Rojas H, Lekic T, Chen W, Jadhav V, Titova E, Martin RD et al. (2008) The antioxidant effects of melatonin after intracerebral hemorrhage in rats. Acta. Neurochir. Suppl 105: 19-21. DOI: 10.1007/978-3-211-09469-3_4.

32 Lekic T, Hartman R, Rojas H, Manaenko A, Chen W, Ayer R, et al. (2010) Protective effect of melatonin upon neuropathology, striatal function, and memory ability after intracerebral hemorrhage in rats. J. Neurotrauma 27: 627-637. doi: 10.1089/neu.2009.1163.

33 Borlongan CV, Yamamoto M, Takei N, Kumazaki M, Ungsuparkorn C, Hida H, et al. (2000) Glial cell survival is enhanced during melatonin-induced neuroprotection against cerebral ischemia. FASEB J. 14: 1307-1317. DOI: 10.1096/fj.14.10.1307.

34 Kondoh T, Uneyama H, Nishino H, Torii K (2002) Melatonin reduces cerebral edema formation caused by transient forebrain ischemia in rats. Life Sci. 72: 583-590. DOI: 10.1016/s0024-3205(02)02256-7.

35 Lin YW, Chen TY, Hung CY, Tai SH, Huang SY, Chang CC, et al. (2018) Melatonin protects brain against ischemia/reperfusion injury by attenuating endoplasmic reticulum stress. Int. J. Mol. Med. 42: 182-192. doi: 10.3892/ijmm.2018.3607.

36 Lee MY, Kuan YH, Chen HY, Chen TY, Chen ST, Huang CC, et al. (2007) Intravenous administration of melatonin reduces the intracerebral cellular inflammatory response following transient focal cerebral ischemia in rats. J. Pineal Res. 42: 297-309. DOI: 10.1111/j.1600-079X.2007.00420.x.

37 Lee EJ, Wu TS, Lee MY, Chen TY, Tsai YY, Chuang JI, et al. (2004) Delayed treatment with melatonin enhances electrophysiological recovery following transient focal cerebral ischemia in rats. J. Pineal Res. 36: 33-42. DOI: 10.1046/j.1600-079x.2003.00093.x. 
38 Alonso-Alconada D, Alvarez A, Lacalle J, Hilario E (2012) Histological study of the protective effect of melatonin on neural cells after neonatal hypoxia-ischemia. Histol. Histopathol. 27: 771-783. doi: 10.14670/HH-27.771.

39 Letechipia-Vallejo G, Lopez-Loeza E, Espinoza-Gonzalez V, Gonzalez-Burgos I, OlveraCortes ME, Morali G, et al. (2007) Long-term morphological and functional evaluation of the neuroprotective effects of post-ischemic treatment with melatonin in rats. J. Pineal Res. 42: 138-146. DOI: 10.1111/j.1600-079X.2006.00395.x.

40 Cuzzocrea S, Costantino G, Gitto E, Mazzon E, Fulia F, Serraino I, et al. (2000) Protective effects of melatonin in ischemic brain injury. J. Pineal Res. 29: 217-27. DOI: 10.1034/j.1600-0633.2002.290404.x.

41 Sun FY, Lin X, Mao LZ, Ge WH, Zhang LM, Huang YL, et al. (2002) Neuroprotection by melatonin against ischemic neuronal injury associated with modulation of DNA damage and repair in the rat following a transient cerebral ischemia. J. Pineal Res. 33: 4856. DOI: 10.1034/j.1600-079x.2002.01891.x.

42 Pei Z, Pang SF, Cheung RT (2003) Administration of melatonin after onset of ischemia reduces the volume of cerebral infarction in a rat middle cerebral artery occlusion stroke model. Stroke 34: 770-775. DOI: 10.1161/01.STR.0000057460.14810.3E.

43 Yang Y, Jiang S, Dong Y, Fan C, Zhao L, Yang X, et al. (2015) Melatonin prevents cell death and mitochondrial dysfunction via a SIRT1-dependent mechanism during ischemicstroke in mice. J. Pineal Res. 58: 61-70. doi: 10.1111/jpi.12193.

44 Wang X, Figueroa BE, Stavrovskaya IG, Zhang Y, Sirianni AC, Zhu S, et al. (2009) Methazolamide and melatonin inhibit mitochondrial cytochrome $\mathrm{C}$ release and are neuroprotective in experimental models of ischemic injury. Stroke 40: 1877-85. doi: 10.1161/STROKEAHA.108.540765.

45 Chen TY, Lee MY, Chen HY, Kuo YL, Lin SC, Wu TS, et al. (2006) Melatonin attenuates the postischemic increase in blood-brain barrier permeability and decreases hemorrhagic transformation of tissue-plasminogen activator therapy following ischemic stroke in mice. J. Pineal Res. 40: 242-50. DOI: 10.1111/j.1600-079X.2005.00307.x.

46 Hung YC, Chen TY, Lee EJ, Chen WL, Huang SY, Lee WT, et al. (2008) Melatonin decreases matrix metalloproteinase-9 activation and expression and attenuates reperfusion-induced hemorrhage following transient focal cerebral ischemia in rats. $J$. Pineal Res. 45: 459-467. doi: 10.1111/j.1600-079X.2008.00617.x.

47 Sugden D (1983) Psychopharmacological effects of melatonin in mouse and rat. $J$. Pharmacol. Exp. Ther. 227: 587-591.

48 Galley HF, Lowes DA, Allen L, Cameron G, Aucott LS, Webster NR (2014) Melatonin as a potential therapy for sepsis: a phase I dose escalation study and an ex vivo whole blood model under conditions of sepsis. J. Pineal Res. 56: 427-438. doi: 10.1111/jpi.12134.

49 Andersen LP, Werner MU, Rosenkilde MM, Harpsoe NG, Fuglsang H, Rosenberg J, et al. (2016) Pharmacokinetics of oral and intravenous melatonin in healthy volunteers. BMC Pharmacol. Toxicol. 17: 8. doi: 10.1186/s40360-016-0052-2.

50 Cardinali DP (2019) Are melatonin doses employed clinically adequate for melatonininduced cytoprotection? Melatonin Res. 2: 106-132. doi: 10.32794/mr11250025.

51 Bazyar H, Gholinezhad H, Moradi L, Salehi P, Abadi F, Ravanbakhsh M, et al. (2019) The effects of melatonin supplementation in adjunct with non-surgical periodontal therapy on periodontal status, serum melatonin and inflammatory markers in type 2 diabetes mellitus patients with chronic periodontitis: a double-blind, placebo-controlled trial. Inflammopharmacology 27 (1): 67-76 doi: 10.1007/s10787-018-0539-0.

52 Sanchez-Lopez AL, Ortiz GG, Pacheco-Moises FP, Mireles-Ramirez MA, BitzerQuintero OK, Delgado-Lara DLC, et al. (2018) Efficacy of melatonin on serum pro- 
inflammatory cytokines and oxidative stress markers in relapsing remitting multiple sclerosis. Arch. Med. Res. 49: 391-398. doi: 10.1016/j.arcmed.2018.12.004.

53 Kucukakin B, Lykkesfeldt J, Nielsen HJ, Reiter RJ, Rosenberg J, Gogenur I (2008) Utility of melatonin to treat surgical stress after major vascular surgery--a safety study. J. Pineal Res. 44: 426-431. doi: 10.1111/j.1600-079X.2007.00545.x

54 Zhao Z, Lu C, Li T, Wang W, Ye W, Zeng R, et al. (2018) The protective effect of melatonin on brain ischemia and reperfusion in rats and humans: In vivo assessment and a randomized controlled trial. J. Pineal Res. 65: e12521. doi: 10.1111/jpi.12521.

55 Shafiei E, Bahtoei M, Raj P, Ostovar A, Iranpour D, Akbarzadeh S, et al. (2018) Effects of $\mathrm{N}$-acetyl cysteine and melatonin on early reperfusion injury in patients undergoing coronary artery bypass grafting: A randomized, open-labeled, placebo-controlled trial. Medicine (Baltimore) 97: e11383. doi: 10.1097/MD.0000000000011383.

56 Chen N, Zhou M, Dong X, Qu J, Gong F, Han Y, et al. (2020) Epidemiological and clinical characteristics of 99 cases of 2019 novel coronavirus pneumonia in Wuhan, China: a descriptive study. Lancet 395: 507-513. doi: 10.1016/S0140-6736(20)30211-7.

57 Huang C, Wang Y, Li X, Ren L, Zhao J, Hu Y, et al. (2020) Clinical features of patients infected with 2019 novel coronavirus in Wuhan, China. Lancet 395: 497-506. doi: 10.1016/S0140-6736(20)30183-5.

58 Volt H, Garcia JA, Doerrier C, Diaz-Casado ME, Guerra-Librero A, Lopez LC, et al. (2016) Same molecule but different expression: aging and sepsis trigger NLRP3 inflammasome activation, a target of melatonin. J. Pineal Res. 60: 193-205. doi: 10.1111/jpi.12303.

59 Dai W, Huang H, Si L, Hu S, Zhou L, Xu L, et al. (2019) Melatonin prevents sepsisinduced renal injury via the PINK1/Parkin1 signaling pathway. Int. J. Mol. Med. 44: 1197 1204. doi: 10.3892/ijmm.2019.4306.

60 Zhang J, Wang L, Xie W, Hu S, Zhou H, Zhu P, et al. (2020) Melatonin attenuates ER stress and mitochondrial damage in septic cardiomyopathy: A new mechanism involving BAP31 upregulation and MAPK-ERK pathway. J. Cell Physiol. 235: 2847-2856. doi: 10.1002/jcp.29190.

61 Chen J, Xia H, Zhang L, Zhang H, Wang D, Tao X (2019) Protective effects of melatonin on sepsis-induced liver injury and dysregulation of gluconeogenesis in rats through activating SIRT1/STAT3 pathway. Biomed. Pharmacother. 117: 109150. doi: 10.1016/j.biopha.2019.109150.

62 Lewandowska K, Malkiewicz MA, Sieminski M, Cubala WJ, Winklewski PJ, MedrzyckaDabrowska WA (2020) The role of melatonin and melatonin receptor agonist in the prevention of sleep disturbances and delirium in intensive care unit - a clinical review. Sleep Med. 69: 127-134. doi: 10.1016/j.sleep.2020.01.019.

63 Mistraletti G, Umbrello M, Sabbatini G, Miori S, Taverna M, Cerri B, et al. (2015) Melatonin reduces the need for sedation in ICU patients: a randomized controlled trial. Minerva Anestesiol. 81: 1298-1310.

This work is licensed under a $\underline{\text { Creative Commons Attribution 4.0 International License. }}$

Please cite this paper as:

Cardinali, D.P. 2020. High doses of melatonin as a potential therapeutic tool for the neurologic sequels of covid-19 infection. Melatonin Research. 3, 3 (Jun. 2020), 311-317. DOI:https://doi.org/https://doi.org/10.32794/mr11250064. 